\title{
DETERMINANTS OF BRAND LOYALTY AND THE LINK BETWEEN BRAND LOYALTY AND PRICE TOLERANCE
}

EBRU TÜMER KABADAYI*

Gebze Institute of Technology

\author{
INCII AYGÜN** \\ Gebze Institute of Technology
}

\begin{abstract}
The aim of this study is to investigate the integrated relationships between brand satisfaction, brand trust and brand affect through the brand loyalty development process and price tolerance as an outcome of the brand loyalty process. Data are collected based on a survey of 1085 students from various universities in Istanbul, Turkey. The findings indicate that brand affect and brand trust are key constructs in the brand loyalty formation process. Brand satisfaction is effective on brand loyalty indirectly through strengthening these constructs. Additionally, brand loyalty is a strong antecedent of consumers' tolerance to price. The research findings will help provide clarification on how brand loyalty comes about and brings about price tolerance.
\end{abstract}

Key words: brand loyalty, brand trust, brand satisfaction, brand affect and price tolerance.

\section{MARKA BA ĞLILIĞINI BELIRLEYEN FAKTÖRLER VE MARKA BAĞLILIĞI ILE FIYYAT TOLERANSININ ILISSKISI}

\begin{abstract}
ÖZET
Bu çalışmanın amacı, marka bağglılı̆̆g geliştirme süreci içinde marka memnuniyeti, markaya duyulan güven ve markanın oluşturduğu duygular arasında iç içe geçmiş ilişkilerin ve marka bağlllı̆̆ sürrecinin çıktısı olarak fiyat toleransin incelenmesidir. Veriler İstanbul'daki çeşitli üniversitelerde okuyan 1085 öğrenci üzerinde yapılan anket çalışması ile toplanmıştır. Bulgular, markanın oluşturduğu duyguların ve markaya duyulan güveninin marka bağlllı̆̆ı oluşturma sürecindeki temel faktörler olduğunu göstermektedir. Marka memnuniyeti ise, bu temel faktörleri güçlendirerek marka bă̆lllı̆̆ dolaylı olarak etkili olmaktadır. Ayrıca, marka bă̆glılı̆̆ııı müssterilerin fiyata olan toleransının güçlü bir öncülü olduğu ortaya çıkmıştır. Araştırmanın bulguları marka bağlllığının nasıl oluştuğunu ve fiyat toleransını nasıl meydana getirdiğini anlamamıza yardımcı olacaktır.
\end{abstract}

Anahtar kelimeler: marka bağlılı̆̆ı, markaya duyulan güven, marka memnuniyeti, markanın oluşturduğu duygular ve fiyat toleransi.

* Ebru Tümer Kabadayı is an Assistant Professor in the Faculty of Business Administration at the Gebze Institute of Technology, Çayırova Fabrika Yolu, No: 101, 41400, Gebze, Kocaeli, Turkey. E-mail: tumer@gyte.edu.tr

** Inci Aygün is a Research Assistant in the Faculty of Business Administration at the Gebze Institute of Technology, Çayırova Fabrika Yolu, No: 101, 41400, Gebze, Kocaeli, Turkey. E-mail: iaygun@gyte.edu.tr 
The long-term success of a brand is not based on the number of consumers who buy it once, but on the number of consumers who become regular buyers of the brand (Odin et al., 2001). This statement simply demystifies firms' strict aims to seek, manage and increase brand loyalty to gain advantage or at least to survive especially in intensely competitive, uncertain, and hardly predictable markets.

Aaker (1996) states that a brand's value to a firm is largely created by the customer loyalty it commands. The literature on brand management provides a large amount of evidence concerning positive outputs related to brand loyalty, such as high profitability and competitive advantage for firms. The increased profit from loyalty comes from price premiums, greater market share (Chaudhuri and Holbrook, 2001) and reduced marketing -operational costs (Bowen and Chen, 2001). As Chaudhuri and Holbrook (2001) proposed and confirmed that brands higher in purchase loyalty are also higher in market share because of greater levels of repeat purchase by brand users and that greater attitudinal loyalty should lead to greater willingness to sacrifice by paying a premium price for a valued brand. Brand loyalty may also help to increase market share indirectly by providing positive word of mouth, which is one of the most powerful sources in persuasion (Selnes, 1993). Because finding new customers and doing business with them takes time, effort and money (Mittal and Lassar, 1998) brand loyalty reduces marketing costs since loyal consumers already know the product and require less information. Ballester and Alleman (2001) indicate other advantages by stating that brand loyalty provides a competitive advantage by generating a substantial entry barrier to competitors, an increase in the firm's ability to respond to competitive threats, and a customer base less sensitive to the marketing efforts of competitors in highly competitive markets. In addition, brand loyalty has been shown to be associated with higher rates of return on investment through increases in market share (Gounaris and Stathakopoulos, 2004).

The benefits of brand loyalty mentioned above, has made it a popular issue for firms and marketing research in the last three decades. It is one of the main purposes of this study to explore the process through which brand loyalty is formed. For this purpose, the effects of brand satisfaction, brand trust and brand affect are investigated.

Another purpose of this study is to investigate price tolerance as an outcome of brand loyalty. The constructs representing consumers' actual or intended reactions to different price levels such as price tolerance, brand acceptance and price premiums are increasingly studied in consumer behavior literature. Aaker's (1996) description of price premium as a reasonable summary of the strength of the brand help to understand the importance of these constructs in brand domain. Price tolerance was included in our research model as a construct representing consumer's differing reactions to different price levels. Although price tolerance is more often proposed to be directly related to satisfaction in previous studies (e.g., Anderson, 1996; Herrmann et al., 2004), in the current study it is investigated as a consequent of brand loyalty.

Although various antecedents and consequents of brand loyalty have been separately evaluated in numerous studies that are formed on different relationship networks, there is still a lack of a clear understanding about the roles of these constructs. For extended and clearer knowledge about the brand loyalty concept the interaction of antecedents and consequents of brand loyalty needed to be investigated. For this purpose, a model was developed using the structural equation modeling approach, which is adequate for evaluating an integrated model. The model contained the key determining constructs that are most commonly mentioned in the brand loyalty literature such as brand satisfaction, brand trust and brand affect and price tolerance as a positive outcome. 
The study begins with describing the literary background of this model. Next, the model is tested and the results are summarized and discussed. Finally, suggestions for future research are given.

\section{FRAMEWORK AND THE HYPOTHESES}

\section{Brand Loyalty}

Brand loyalty has been investigated for a long time by researchers and there are ample studies on this concept. However, due to the different perspectives in the literature, there are diverse definitions of brand loyalty. In 1973, Jacoby and Kyner pointed out the problem of the definitions and operationalization of the construct, stating that so many definitions made it difficult and hazardous to compare, synthesize and accumulate findings. It appears that the complexity of the construct of loyalty still prevents the formulation of a unique definition in the recent literature. Thiele and Mackay (2001) state that in the marketing literature the term "loyalty" has been used interchangeably with its operational definition to refer to repeat purchase, preference, commitment, retention and allegiance. These terms are the outputs of definitions that are related to the different aspects of brand loyalty.

Quester and Lim (2003) state that the literature shows two alternative approaches to the construct of brand loyalty. The first one is concerned with "a consistent purchase behavior of a specific brand over time." This is the behavioral approach to brand loyalty and it has been widely used to define the construct. The second one relies on a favorable attitude towards a brand.

Neither approach seems to be sufficient by itself to define brand loyalty completely as both ignore either the psychological or behavioral dynamics of the concept. One problem with the behavioral approach is that repeat purchases are not always the result of a psychological commitment to the brand (Bowen and Chen, 2001). Especially for low involvement products, repeat purchasing of the same brand may be a habitual action to avoid spending the time and effort necessary for evaluating alternative brands. The attitudinal approach, which includes emotional and psychological attachment to a brand, also

Figure 1

\section{Theoretical Model}




has some problems as there may be reasons that prevent the consumer from purchasing the brand he/she loves or has an attachment. Quester and Lim (2003) indicate that true brand loyalty implies a commitment to a specific brand and goes beyond repetitive behavior. In this study, consistent with this idea, the concept of brand loyalty includes behavioral intention to buy the same brand and recommend it to others. To encourage others to buy with strong recommendation emphasizes the attitudinal aspect of brand loyalty and the purchase intention emphasizes the behavioral aspect.

In the marketing literature, there are numerous studies that aimed to explore the sources and outputs of brand loyalty. As has been stated before, the interaction of brand satisfaction, trust and affect through generating brand loyalty and price tolerance as a positive outcome of it will be examined in this study. The proposed model is presented in Figure 1.

\section{Brand Satisfaction}

Satisfaction is defined as pleasurable fulfillment, which means the consumer senses that consumption fulfills some need, desire, goal or so forth and that this fulfillment is pleasurable (Oliver, 1999). It is the result of a cognitive and affective evaluation where some comparison standard is compared to actually perceived performance (Homburg and Giering, 2001). When the subject is a brand, the evaluation output appears as brand satisfaction versus brand dissatisfaction. Consistent with satisfaction definitions above, in this study, brand satisfaction is conceptualized as the outcome of the subjective evaluation that the chosen alternative brand meets or exceeds expectations (Lou and Lee, 1999). Satisfaction is regarded as a fundamental determinant of long-term consumer behavior (Ranaweera and Prabhu, 2003), thereby, as one of the key global constructs predicting consumer behavior (Garbarino and Johnson, 1999).

Although it is known that brand satisfaction has a role in developing brand loyalty, the complexity of the link between these two constructs makes it hard to get a full understanding. Because of the fact that only a relatively small portion of satisfied customers returns to the same service or product (White and $\mathrm{Yu}, 2005)$ and because merely satisfying customers that have the freedom to make choices is not enough to keep them loyal (Oliver, 1999), brand satisfaction is likely to need some other constructs as mediating actors to be effective on brand loyalty. In this study, it is proposed that brand satisfaction has an indirect effect on brand loyalty through strengthening brand trust and brand affect.

Consumers buy products/services to obtain certain physical and/or psychological benefits. So to be willing to stay in a long-term relationship with the brand they are very likely to need to believe that the brand will constantly provide the same benefits and satisfaction with every product with the same brand name. So brand trust is needed as a mediating actor between brand satisfaction and brand loyalty.

The satisfaction $\rightarrow$ trust relationship can be proposed based on the characteristics and development processes of these constructs. Because trust requires an assessment of the other party's credibility and benevolence, one party must have information about the other party's past behavior and promises (Doney and Cannon, 1997); that is, consumption experience is the most relevant and important source of brand trust because it generates associations, thoughts and inferences that are more self-relevant and held with certainty (Balester and Aleman, 2005). Satisfaction, as mentioned above, is a post-choice evaluative judgment of a specific transaction (Selnes, 1993) and can provide the necessary information for the brand trust assessment. Lou and Lee (1999) also state satisfaction with past outcomes indicates equity in the exchange. This increases the perception of the exchange partner's benevolence and 
credibility, because when a consumer is satisfied with a brand after using it, this situation is similar to promise fulfillment. Since the brand has kept its promise, the consumer is liable to trust it more.

\section{Hypothesis 1: Brand satisfaction is positively related to brand trust.}

Furthermore, the brand satisfaction-brand loyalty relationship is suggested also to have brand affect as another mediating actor. Brand satisfaction affects brand loyalty indirectly by evoking positive feelings about the brand because of the benefits it provides.

\section{Hypothesis 2: Brand satisfaction is positively related to brand affect}

This suggested relationship may also mean the indirect effect of satisfaction on brand trust because of the suggested effect of brand affect on brand trust that will be discussed below.

\section{Brand Trust}

Morgan and Hunt (1994) conceptualize trust as existing when one party has confidence in an exchange partner's reliability and integrity. Probably because it is generally viewed as an essential ingredient for successful relationships, as stated in Garbarino and Johnson (1999), trust is one of the most frequently mentioned factors in the relational marketing literature (Morgan and Hunt, 1994; Doney and Cannon, 1997; Selnes, 1998; Lau and Lee, 1999; Chaudhuri and Holbrook, 2001; Ballester and Aleman, 2005).

In the brand-consumer relationship, trust should also be a crucial factor. It should be important to build a trustworthy image for the brand because in most cases consumers seem to meet the brand of a product/service before meeting the producer, salesperson, etc. Ballester and Aleman (2005) define a trustworthy brand as one that consistently keeps its promise of value to consumers through the way the product is developed, produced, sold, serviced and advertised, even in bad times when some kind of brand crisis arises. Following the definitions, it is not hard to relate brand trust to brand loyalty, logically. Previous studies strengthen this expectation.

Morgan and Hunt (1994) explain the trust $\rightarrow$ commitment link by pointing out that relationships characterized by trust are so highly valued that parties will desire to commit themselves to such relationships. Doney and Cannon (1997) also state that the high level of trust characteristic of relational exchange enables parties to focus on the long-term benefits of the relationship.

Chaudhuri and Holbrook (2001) suggest that brand trust leads to brand loyalty or commitment, because trust creates an exchange relationship that one is highly involved. Indeed, commitment has been defined as an enduring desire to maintain a valued relationship. Thus, loyalty or commitment underlies the ongoing process of maintaining a valued relationship that has been created by trust. In other words, trust and commitment should be associated because trust is important in relational exchanges and commitment is also reserved for such valued relationships.

In this context, it can be proposed that a trusted brand should be purchased more often and should evoke a higher degree of attitudinal commitment. If the consumer trusts the brand he/she will be more likely to build a long-term relationship with the brand that includes positive behavioral intention and attitudinal loyalty. 


\section{Brand Affect}

According to Westbrook (1987), affect is to compromise a class of mental phenomena uniquely characterized by a consciously experienced, subjective feeling state, commonly accompanying emotions and moods. In the same study, Westbrook (1987) points out that advances in social cognition, cognitive psychology and social psychology suggest that affective processes may constitute not only a powerful source of human motivation, but also influence information processing and choice. It appears that the affective process may be a determinant of consumer behavior in the long term. In this study, affective responses related to usage of a brand are proposed as antecedents of brand trust and brand loyalty. Following Chaudhuri and Holbrook (2001), brand affect is defined as a brand's potential to elicit a positive emotional response in the average consumer as a result of its use.

As mentioned above, the brand affect is supposed to be effective on brand loyalty both in a direct and an indirect way. Indirectly, positive brand affect will be effective on building brand loyalty by increasing trust feeling for that brand. As affective responses have been shown to be able to influence cognitive processes such as evaluation, recall and judgment (Nyer, 1997), consumers' affective response to a brand usage is likely to be effective on the formation of brand trust. So it can be proposed that having positive consumption elicited affective response related to brand may enable attributing a trustworthy image to that brand.

\section{Hypothesis 4: Brand affect is positively related to brand trust}

In addition, brand affect can be proposed as being affective on loyalty directly because loyalty will be greater under the condition of more positive emotional mood or affect. That is, brands that make consumers happy or joyful or affectionate should prompt greater purchase and attitudinal loyalty (Chaudhuri and Holbrook, 2001). In other words, positive emotional mood or affect about a brand will encourage loyalty.

\section{Hypothesis 5: Brand affect is positively related to brand loyalty}

\section{Price Tolerance}

Price tolerance can be described as the reaction of customers to the price increase of a specific product and is constructed as a price span within the boundaries of which the consumer does not change his/ her buying behavior. In this way, the tolerated price range stretches from the actual price paid by the consumer to the maximum price that a consumer is willing to pay for the product (Herman et al., 2004). Definitions of the constructs above are likely to help us build the logical link between brand loyalty and price tolerance. But it is also possible to find evidence for this link in some studies that investigate consumers' price acceptance. For instance, Huber et al., (2000) investigate the relationship between customer satisfaction and price acceptance that was conceptualized as the potential buyers' willingness to purchase as a function of various prices. As seen in this aspect, price tolerance is likely to represent the latitude of brand acceptance. Latitude of brand acceptance is a concept that also was used in Kalyanaram and Little (1994), who made an empirical analysis of the latitude of price acceptance in consumer packaged goods. They suggest that consumers who are on the average more 
brand loyal in a given product category would be likely to have a wider latitude of price acceptance for that brand because brand loyalty would keep the consumer more focused on the benefits of the brand and less focused on price. Chaudhuri and Holbrook (2001) found a positive relationship between favorable brand attitude and being more willing to pay premium prices for a brand.

Hypothesis 6: Brand loyalty is positively related to price tolerance

\section{METHOD}

\section{Data Collection}

Although it may reduce the external validity of the study by limiting the general use of the findings, data were collected with respect to only one product category, namely jeans. Studying only one product category may highlight the process through which brand loyalty forms and leads to price tolerance more clearly by eliminating the differences in response patterns due to different reference points. Jeans were chosen as the product category because most people are familiar with them, they are purchased by different segments of the population and there are many alternative brands with different quality, price, reputation, etc. Also, this product may address both utilitarian and hedonic needs that may help to satisfy constructs' different aspects if available.

Data were collected from a sample composed of students from nine universities located in Istanbul, Turkey. The universities were chosen considering their type and location. Two private and two public universities on the European side of Istanbul and three public and two private universities on Asian side were chosen. A total of 1117 questionnaires were delivered to students on the campuses of these universities.

Respondents were asked to name the jean brand they had bought most recently and answered the questions thinking about that brand. After the elimination of some received questionnaires due to excessive amounts of missing data, 1085 were used for analysis that were substantially complete and resulted in a valid response rate of $82.74 \%$.

\section{Measurement}

Brand satisfaction was measured using a scale developed by Lau and Lee (1999). Of the seven items in the scale, five items were used, of which three were reversed. Items aimed to measure consumers' cognitive reactions related to product usage. The operationalization of brand affect involved adapting Chaudhuri and Holbrook's (2001) three-item scale, which measures consumer's post-consumption positive affective responses. Chaudhuri and Holbrook's (2001) three-item scale was supplemented by an additional item from the study of Lou and Lee (1999), and the resulting four-item scale was used to measure brand trust. It involved items that aimed to explore directly whether the consumer felt security about the brand. Eight items were used to measure brand loyalty, composed of the behavioral and attitudinal aspects of the construct. Items were drawn from Lou and Lee's scale (1999). Finally, following Ballester and Aleman (2001), price tolerance was measured by asking respondents if they would be willing to pay more for the brand compared to other brands. Measurement items are represented in Table 2 . 
All variables were measured based on a five-point Likert scale ranging from $1=$ strongly disagree to $5=$ strongly agree. The questionnaire was pre-tested with 45 university students, and the final questionnaire was developed with revision of some items for clarity of wording. To avoid response bias, the questionnaire was designed in two forms including the same scale items but in different order.

\section{DATA ANALYSIS AND RESEARCH RESULTS}

Table 1 gives summary information about the sample profile. As can be seen, the sample is highly concentrated $(74.9 \%)$ in the $20-24$ age range. Most of the participants were unemployed respondents from public universities with incomes in the 1000-2500 YTL income range.

Table 1

\section{Sample Statistics}

\begin{tabular}{|c|c|c|c|c|c|c|}
\hline & & & & & $\begin{array}{l}\text { Monthly } \\
\text { personal } \\
\text { income * }\end{array}$ & $\begin{array}{l}\text { Monthly } \\
\text { household } \\
\text { income }\end{array}$ \\
\hline & $\underline{\text { Percent }}$ & & $\underline{\text { Percent }}$ & & $\underline{\text { Percent }}$ & $\underline{\text { Percent }}$ \\
\hline Gender & & Employment status & & $\begin{array}{l}\text { Less than } \\
\text { 300YTL }\end{array}$ & 22.7 & 1.3 \\
\hline Male & 40.4 & $\begin{array}{l}\text { Employed } \\
\text { (full or part-time) }\end{array}$ & 15 & $\begin{array}{l}300-600 \\
\text { YTL }\end{array}$ & 36.7 & 9.3 \\
\hline Female & 59.6 & Unemployed & 85 & $\begin{array}{l}\text { 601-999 } \\
\text { YTL }\end{array}$ & 15.1 & 13.8 \\
\hline Age & & & & $\begin{array}{l}1000-1499 \\
\text { YTL }\end{array}$ & 12.6 & 22.3 \\
\hline $\begin{array}{l}\text { From } 15 \\
\text { to } 19\end{array}$ & 19 & University type & & $\begin{array}{l}1500-2499 \\
\text { YTL }\end{array}$ & 10.9 & 17.5 \\
\hline $\begin{array}{l}\text { From } 20 \\
\text { to } 24\end{array}$ & 74.9 & Public university & 68.1 & $\begin{array}{l}2500-3499 \\
\text { YTL }\end{array}$ & & 10.1 \\
\hline $\begin{array}{l}\text { From } 25 \\
\text { to } 29\end{array}$ & 5.9 & $\begin{array}{l}\text { Private university } \\
\text { (with scholarship) }\end{array}$ & 9.1 & $\begin{array}{l}3500-5000 \\
\text { YTL }\end{array}$ & 1.7 & 9.1 \\
\hline $\begin{array}{l}30 \text { and } \\
\text { older }\end{array}$ & 0.4 & $\begin{array}{l}\text { Private university } \\
\text { (no scholarship) }\end{array}$ & 22.8 & $\begin{array}{l}\text { More than } \\
5000 \text { YTL }\end{array}$ & 0.8 & 16.6 \\
\hline
\end{tabular}

* Monthly personal income represents income of employed respondents

\section{Validity and Reliability of Scale}

Initially an exploratory factor analysis was carried out employing principal component analysis and rotated using varimax rotation. A total of two items were eliminated, one from the brand satisfaction scale and one from the brand loyalty scale, of which the loading on respective factor was below 0.5 . Then all measures were analyzed for validity and reliability through confirmatory factor analysis. 
A purified full measurement model was proposed with four reflective multiple item factors: brand satisfaction, brand trust, brand affect, brand loyalty (with attitudinal and behavioral dimensions). The single item factor "price tolerance" was added to the model, setting its measurement error at $10 \%$ variance of respective factor. This full measurement model was tested in AMOS 5 using the maximum likelihood estimation techniques. As presented in Table 2, Goodness of Fit Index $(\mathrm{GFI})=0.91$; Comparative Fit Index $(\mathrm{CFI})=0.92$; Root Mean Square Error of Approximation $($ RMSEA $)=0.07$ were in acceptable ranges although the chi-square statistic was very large $\left(\chi_{(141)}^{2}=1027.032 \mathrm{p}<0.01\right)$, probably due to the large sample size.

To assess the reliability, the Cronbach's alpha coefficient and composite reliability scores were calculated. As presented in Table 2 composite reliability scores were well over the critical level 0.6 (Fornell and Larcker, 1981) and the Cronbach's alpha coefficients were over 0.7 (Nunnaly, 1978) indicating reliability of the measurement model. Estimates of paths from individual items to latent factors are also show in Table 2 and they are all significant $(\mathrm{p}<0.01)$, providing evidence for convergent validity.

Discriminant validity was evaluated based on Fornell and Larcker's (1981) criterion. The shared variance between pairs of latent factors in the structural measurement model was compared with average variance extracted that was calculated for each component of pairs. It was found that average variance extracted was greater, providing evidence for discriminant validity. It can be concluded on the basis of the reliability and validity analysis that scales for the constructs appear to have acceptable measurement quality. The means, standard deviations (SD) and inter-correlations among variables are represented in Table 3. In this table, the upper part represents the correlations among latent factors, and the part below represents the correlations among aggregated measures.

\section{Tests of the Hypotheses}

The proposed research model, presented in Figure 1, was tested using the maximum likelihood method in AMOS 5. Goodness of fit statistics were at the acceptable levels (GFI $=0.90$; CFI $=0.91$; RMSEA $=0.07$ ), supporting the overall fit of proposed model to our data, although the chi-square statistic was $\chi^{2}{ }_{(141)}=1028.974 \mathrm{p}<0.01$. The unexpectedly large chi-square value can be attributed to the relatively large sample size in our research. Also the standardized estimates, shown in Table 4, are all significant at $\mathrm{p}<0.01$ indicating that all of the hypothesized links are supported. Links, their standardized estimates, and significance levels are presented in Table 4.

The results for $H 1$ and $H 2$ support the conclusion that consumers' satisfaction with a brand is effective on both developing trust and positive affect to that brand. Also $H 4$, suggesting the positive relationship between brand affect and brand trust, was supported, meaning that consumers' positive feeling about using that brand is effective on building trust towards that brand.

Continuing with the antecedents of brand loyalty, the research results present empirical support for the positive effect of brand trust and brand affect on developing brand loyalty as hypothesized by $H 3$ and H5. The standardized estimates reveal that brand loyalty depends on brand trust a little more than brand affect $(0.497$ and $0.428 ; \mathrm{p}<0.01)$. Finally, considering the consequents of brand loyalty, results confirm that brand loyalty has an influence on the price tolerance of consumers. Thus, the last hypothesis $H 6$ was also supported. 
Table 2

Measurement Items




Table 3

Descriptive Statistics

\begin{tabular}{lllccccc}
\hline & Mean & Std. Deviation & 1 & 2 & 3 & 4 & 5 \\
\hline 1.Brand Satisfaction & 4.0645 & .7321 & 1 & $.47 * *$ & $.29 * *$ & $.36^{* *}$ & $.25^{* *}$ \\
2.Brand Trust & 3.4126 & .8775 & $.41^{* *}$ & 1 & $.65^{* *}$ & $.78^{* *}$ & $.55^{* *}$ \\
3.Brand Affect & 3.3015 & 1.0532 & $.29 * *$ & $.58^{* *}$ & 1 & $.75^{* *}$ & $.56^{* *}$ \\
4.Brand Loyalty & 2.8890 & .8127 & $.28^{* *}$ & $.63^{* *}$ & $.61^{* *}$ & 1 & $.74 * *$ \\
5.Price Tolerance & 2.79 & 1.32 & $.24 * *$ & $.49^{* *}$ & $.51^{* *}$ & $.61 * *$ & 1 \\
\hline
\end{tabular}

$* * \mathrm{p}<0.01$

Table 4

The Standardized Path Estimates and Fit Statistics

\begin{tabular}{|c|c|c|c|c|c|c|}
\hline Hypotheses & Lin & & Estimate & S.E. & C.R. & $\mathrm{P}$ \\
\hline$H 1$ & Brand Satisfaction $\rightarrow$ & Brand Trust & .302 & .039 & 9,611 & .000 \\
\hline$H 2$ & Brand Satisfaction $\rightarrow$ & Brand Affect & .294 & .052 & 8,270 & .000 \\
\hline$H 3$ & Brand Trust & Brand Loyalty & .497 & .035 & 12,629 & .000 \\
\hline$H 4$ & Brand Affect & Brand Loyalty & .428 & .028 & 11,466 & .000 \\
\hline H5 & Brand Affect & Brand Trust & .556 & .026 & 17,973 & .000 \\
\hline H6 & Brand Loyalty & Brand Tolerance & .732 & .061 & 19,604 & .000 \\
\hline
\end{tabular}

Chi-square $=1028.974$

Degrees of freedom $=145$

Probability level $=0.000$

Goodness of fit index $($ GFI $)=0.90$

Comparative fit index $(\mathrm{CFI})=0 . .91$

Root mean square error of approximation $($ RMSEA $)=0.07$

Table 5

Results of the Hypothesis Tests

\begin{tabular}{cllll}
\hline Hypotheses & & Link & & Results \\
\hline$H 1$ & Brand Satisfaction & $\rightarrow$ & Brand Trust & Supported \\
$H 2$ & Brand Satisfaction & $\rightarrow$ & Brand Affect & Supported \\
$H 3$ & Brand Trust & $\rightarrow$ & Brand Loyalty & Supported \\
$H 4$ & Brand Affect & $\rightarrow$ & Brand Loyalty & Supported \\
$H 5$ & Brand Affect & $\rightarrow$ & Brand Trust & Supported \\
$H 6$ & Brand Loyalty & $\rightarrow$ & Brand Tolerance & Supported \\
\hline
\end{tabular}




\section{DISCUSSION}

This study investigates the roles of brand satisfaction, affect and trust as interacted antecedents of brand loyalty and the link between brand loyalty and price tolerance. The analysis results provide support for all linkages that are hypothesized in the research model.

In the literature, satisfaction is frequently investigated in various positions as one of the main antecedents of loyalty. In the present study, it was supposed that satisfaction would be in an indirect relationship with brand loyalty. In the research model proposing that consumer's satisfaction would require some mediating actors to affect brand loyalty, the satisfaction $\rightarrow$ brand loyalty direct relationship was not allowed. The acceptable fit statistics confirmed this overall proposition. Moreover, modification indices were checked and it was found that there was no other link needed. This finding provides additional support for the suggestion about the indirect relationship between brand satisfaction and brand loyalty. In this indirect relationship, the mediating role of brand trust and brand affect can be seen clearly. The results confirmed $\mathrm{Hl}$ that supposed the link of brand satisfaction $\rightarrow$ brand trust (estimatel $=0.30 \mathrm{p}<0.01$ ). Brand satisfaction was also found to have an effect on brand affect (estimate $2=0.29$ $\mathrm{p}<0.01)$ as stated in $H 2$. It seems that consumer's satisfaction level was effective at a similar level both on being formed of positive feelings about using the brand and the trustworthy image of the brand. In the research model it was also proposed that consumers who like using a brand would be more inclined to find a positive result at the end of the evaluation about the trustworthiness of that brand. Analysis results confirmed $H 4$, which proposed that brand affect would be effective on brand trust. In other words, consumers are influenced by their feelings of using that brand in attributing a trustworthy image to that brand (estimate $4=0.56 \mathrm{p}<0.01$ ). In this relationship network, half of the variance in brand trust is explained by brand satisfaction and brand affect. But the brand affect factor was explained in the ratio of $9 \%$. It seems that there is another factor(s) effecting consumer's feelings about brand that was not proposed in the research model.

In the research model, brand trust and brand affect were proposed to be antecedents of brand loyalty. It was not unexpected to see a direct and quite strong effect of brand trust on brand loyalty as $\mathrm{H3}$ (estimate $3=0.50 \mathrm{p}<0.01$ ) because the important role of trust as a direct and also as a mediating factor was mentioned before in the brand and relationship literature (Lau and Lee, 1999; Chaudhuri and Holbrook, 2001; Ballester and Aleman, 2005, e.g.) and supported by empirical evidence. In this study, additionally another key variable, brand affect was proposed to be effective on brand loyalty directly. The role of brand affect in the process in which brand loyalty comes about is nearly as strong as brand trust having a significant direct effect as stated in $H 5$ (estimate $5=0.43 \mathrm{p}<0.01)$ and also playing a mediating role between brand satisfaction and brand loyalty. The strong role of brand affect in this process can be attributed to the sample profile and the product category for which the research data were collected. Clothes may be perceived as a social status symbol among university student, which may increase the relative effect of feelings on decisions, choice or judgments about the brand. Future examination of the results about these relationships has shown that brand trust and brand affect explain a very satisfactory amount of the observed variance in brand loyalty with a 0.70 squared multiple correlation value. It was an important finding as one of the main purposes of the study was to examine the process through which brand loyalty develops. 
The results also present some important explanations about how consumers would be motivated to be ready to pay premium prices for the brand. Different from some earlier findings (Hermann et al., 2004; Huber et al., 2000, e.g.) indicating a direct relationship between satisfaction and price tolerance, the present results show that satisfaction affects price tolerance indirectly through brand affect, brand trust, and brand loyalty. Evaluation of the modification indices strengthens this finding offering no additional link. As stated in $H 6$, consumers' willingness to pay premium price for a brand is directly related to how loyal they are to that brand. And this relation was found so strong (estimate6 $=0.73 \mathrm{p}<0.01$ ) that brand loyalty was able to explain more than half of the variance observed in price tolerance. It appears that the acceptability of price levels for a brand is strongly influenced by how strongly consumers intend to buy the same brand again and re-patronize it.

It is a clear fact that firms that aim not only to make their brands survive in intensively competitive markets but also outperform the rivals have to pay great attention to brand loyalty. Firms can take advantage of price tolerance and some other consequences if they succeed at creating, maintaining and increasing brand loyal consumer portfolios. But it is not always easy to acquire consumers willing in a long-term relationship with a brand, especially in some markets where numerous alternatives with similar offerings exist.

As for the antecedents, satisfaction was seen as the main factor in the process of establishing brand loyalty. But the findings of this research extend some previous insights that satisfaction may not be enough to make consumers loyal to one brand over others. In parallel with the theoretical suggestions of previous studies, our current empirical findings also stress the necessity of a trustworthy image for a brand to gain a loyal consumer portfolio. Another important finding is the evidence about the relationship between consumption-evoked emotions and brand loyalty. In their marketing policies companies should concentrate on deeper market research to acquire complete knowledge about the dynamics of affective responses to be capable of providing consumers to feel so happy, pleasant and so forth. Through these efforts companies can develop consumer willingness to stay in a long-term relationship with their brands.

\section{LIMITATIONS AND FURTHER RESEARCH IMPLICATIONS}

The results of this study have several limitations that should be considered. The generalization of the findings is limited because of the limited variety in the sample profile. Another limitation is that the data were collected with respect to only one product. In terms of future research, these limitations point to the need to expand the variety of sample profiles and products on which the research is based.

The findings of this study also lead to some other suggestions for future research. The research model can be refined by evaluating some other primary consequents of brand loyalty. On the other hand, a better understanding of the process in which brand loyalty is secured through brand affect can be reintroduced into the model as a multi-dimensional construct providing more information about consumers' affective response to brand usage. In addition, future research can provide extended knowledge about the brand loyalty concept by also considering some components of the cognitive process in which consumer engage in decision- making about brands. 


\section{REFERENCES}

Anderson, E.W. (1996). “Consumer Satisfaction and Price Tolerance,” Marketing Letters, 7(3):265274.

Aaker, D.A. (1996). Building Strong Brand. London: Free Press.

----- (2006). "Measuring Brand Equity across Products and Markets," California Management Review, 38(3): 102-120.

Ballester, E.D. and Alleman, J.L.M. (2001). "Brand Trust in the Context of Consumer Loyalty," European Journal of Marketing, 35(11/12): 1238-1258.

(2005). "Does Brand Trust Matter to Brand Equity?" Journal of Brand Management, 14(3): 187-196.

Bowen, J.T. and Chen, S.L. (2001). "The Relationship between Customer Loyalty and Customer Satisfaction,” International Journal of Contemporary Hospitality Management, 13(5): 213-217.

Chaudhuri, A. and Holbrook M.B. (2001). "The Chain Effects from Brand Trust and Brand Affect to Brand Performance: The Role of Brand Loyalty,” Journal of Marketing, 65(2): 81- 93.

Doney M.P. and Cannon, J.P. (1997). "An Examination of the Nature of Trust in Buyer-Seller Relationships," Journal of Marketing, 61(2): 35-51.

Fornell, C. and Larcker, D.F. (1981). "Evaluating Structural Equation Models with Unobservable Variables and Measurement Error," Journal of Marketing Research, 18(01): 39-50.

Garbarino, E. and Johnson, M.S. (1999). “The Different Roles of Satisfaction, Trust and Commitment in Customer Relationship," Journal of Marketing, 63(2): 70-87.

Gounaris, S. and Stathakopoulos, V. (2004). "Antecedents and Consequences of Brand Loyalty: An Empirical Study,” Journal of Brand Management, 11(4): 283-306.

Hermann, A., Huber, F., Sivakumar, K., and Wricke, M. (2004). "An Empirical Analysis of the Determinants of Price Tolerance," Psychology \& Marketing, 21(7): 533.

Homburg, C. and Giering, A. (2001). "Personal Characteristics as Moderators of the Relationship between Customer Satisfaction and Loyalty-An Empirical Analysis," Psychology and Marketing, 18(1): 43-66.

Huber, F., Herrmann, A., and Wricke, M. (2001). "Consumer Satisfaction As an Antecedent of Price Acceptance: Results of an Empirical Study," Journal of Product and Brand Management, 10(3): 160169. 
Jacoby, J. and Kyner, D.B. (1973). "Brand Loyalty vs. Repeat Purchasing Behavior,” Journal of Marketing Research, 10(01): 1-9.

Kalyanaram, G. and Little, J.D.C. (1994). “An Empirical Analysis of Latitude of Price Acceptance in Consumer Package Goods,” Journal of Consumer Research, 21(3): 408-41.

Lou, G.T. and Lee, S.H. (1999). "Consumers' Trust in a Brand and Link to Brand Loyalty," Journal of Market Focused Management, 4: 341-370.

Mittal, B. and Lassar, W.M. (1998). "Why Do Customers Switch? The Dynamics of Satisfaction Versus Loyalty,” The Journal of Services Marketing, 12(3): 177-194.

Morgan, R.M. and Hunt, S.D. (1994). "The Commitment Trust Theory of Relationship Marketing," Journal of Marketing, 53(3): 20-38.

Nyer, P.U. (1997). "A Study of Relationships between Cognitive Appraisals and Consumption Emotions," Academy of Marketing Science Journal, 25(4): 296-304.

Nunnaly, J.C. (1978). Psychometric Theory. 2nd ed. New York: McGraw Hill.

Odin Y., Odin, N., and Florence, P.V. (2001). "Conceptual and Operational Aspects of Brand Loyalty: An Empirical Investigation,” Journal of Business Research, 53: 75-84.

Oliver, R. L. (1999). “Whence Consumer Loyalty?” Journal of Marketing, 63: 33-44.

Quester, P. and Lim, A.L. (2003). "Product Involvement /Brand Loyalty: Is There a Link?" The Journal of Product and Brand Management, 12(1): 22-38.

Ranaweera, C. and Prabhu, J. (2003). "The Influence of Satisfaction, Trust and Switching Barriers on Customer Retention in a Continuous Purchasing Setting," International Journal of Service Industry Management, 14(4): 374-395.

Selnes, F. (1993). “An Examination of Effect of Product Performance on Brand Reputation, Satisfaction and Loyalty,” European Journal of Marketing, 27(9): 19-35.

----- (1998). "Antecedents and Consequences of Trust and Satisfaction in the Buyer-Seller Relationship,” European Journal of Marketing, 32(3/4): 305.

Thiele, S.R. and Mackay, M.M. (2001). "Assessing the Performance of Brand Loyalty Measures," The Journal of Services Marketing, 15(7): 529-546.

Westbrook, R.A. (1987). "Product/Consumption-Based Affective Responses and Post Purchase Processes," The Journal of Marketing Research, 24(3): 258-270.

White, C. and Yu, Y.T. (2005). "Satisfaction Emotions and Consumer Behavioral Intentions," Journal of Service Marketing, 19(6): 411-420. 